\title{
Interleukin 6 Is Autoregulated by Transcriptional Mechanisms in Cultures of Rat Osteoblastic Cells
}

\author{
Nathalie Franchimont, ${ }^{\star}$ Sheila Rydziel, ${ }^{\star}$ and Ernesto Canalis ${ }^{\star} \ddagger \S$ \\ $*$ Department of Research and ${ }^{\ddagger}$ Department of Medicine, Saint Francis Hospital and Medical Center, Hartford, Connecticut 06105; and \\ ${ }^{\S}$ The University of Connecticut School of Medicine, Farmington, Connecticut 06030
}

\begin{abstract}
Interleukin 6 (IL-6), a cytokine produced by skeletal cells, stimulates osteoclast recruitment. The IL-6 soluble receptor (sIL-6R) increases IL-6 activity, and IL-6 and sIL-6R levels are increased in conditions of increased bone resorption. We examined the production of IL- 6 by primary rat osteoblasts ( $\mathrm{Ob}$ cells) cultured in the presence of IL-6 and sIL-6R. IL-6 alone did not induce IL-6 transcripts, but IL-6 was stimulatory in the presence of sIL-6R. Furthermore, sIL-6R by itself increased IL-6 transcripts. Cycloheximide superinduced IL-6 transcripts and did not prevent the effect of IL-6 and sIL-6R. IL-6 in the presence of sIL-6R stimulated IL-6 rates of transcription and the activity of IL- 6 promoter fragments in transiently transfected $\mathrm{Ob}$ cells. 5' deletions of the IL-6 promoter and targeted mutations of the multiple response element (MRE)/cAMP responsive element (CRE), the nuclear factor for IL-6 (NF-IL-6), and the nuclear factor- $\kappa B$ $(\mathrm{NF}-\kappa \mathrm{B})$ binding sites indicated that NF-IL-6 and NF- $\mathrm{B}$, in combination with MRE/CRE, binding sites are required for the induction of the IL-6 promoter by IL-6. In conclusion, IL-6 induces its own synthesis in osteoblasts by transcriptional mechanisms. This positive feedback may be important in conditions of increased bone resorption. (J. Clin. Invest. 1997. 100:1797-1803.) Key words: bone remodeling • osteoporosis • cytokines • DNA-binding sites • transcription factors
\end{abstract}

\section{Introduction}

Interleukin 6 (IL-6), a pleiotropic cytokine with osteotropic activities, is produced by multiple cells in the skeletal tissue, including cells of the osteoblast and osteoclast lineage (1, 2). IL-6 is considered an autocrine or paracrine mediator of bone resorption since it stimulates the development of osteoclasts from precursor cells $(2,3)$. IL-6 production in skeletal cells is stimulated by hormones, such as parathyroid hormone and 1,25-dihydroxyvitamin $\mathrm{D}_{3}$, and by local cytokines, such as TNF and IL-1 (4-7). IL-6 may be an important intermediary in the

Address correspondence to Ernesto Canalis, M.D., Department of Research, Saint Francis Hospital and Medical Center, 114 Woodland Street, Hartford, CT 06105-1299. Phone: 860-714-4068; FAX: 860714-8053.

Received for publication 19 June 1997 and accepted in revised form 12 August 1997.

J. Clin. Invest.

(C) The American Society for Clinical Investigation, Inc. 0021-9738/97/10/1797/07 \$2.00

Volume 100, Number 7, October 1997, 1797-1803

http://www.jci.org effects of these agents on bone resorption, and it appears to mediate the bone loss observed in the estrogen-deficient state (8). Myeloma cells are a source of IL-6, and thus, this cytokine may also be responsible for the increased bone resorption observed in patients with multiple myeloma (9-11).

Although IL-6 appears to play a pivotal role in bone resorption, its mechanism of action is poorly understood. In coculture systems of mouse osteoblasts and bone marrow cells, IL-6 stimulates the formation of multinucleated osteoclast-like cells in the presence but not in the absence of the IL-6 soluble receptor $\left(\right.$ sIL-6R) ${ }^{1}$ (12). sIL-6R can be generated by proteolytic cleavage of the IL-6 membrane-bound receptor, an $80-\mathrm{kD}$ glycoprotein (gp-80), or by translation of an alternatively spliced RNA (13-15). Signal transduction occurs after the binding of IL-6 to gp-80 and the association of the complex with two 130-kD glycoproteins (gp-130). The cytoplasmic domain of gp-80 is not required for IL-6 signaling, and the sIL-6R can mediate IL-6 signals since it retains ligand-binding activity (16).

sIL-6R has been detected in biological fluids such as plasma, urine, and synovial fluid of healthy humans, and its levels, like those of IL-6, are elevated in conditions of increased bone resorption, such as multiple myeloma and estrogen deficiency (17-19). This suggests that not only IL-6 but also its soluble receptor play a role in bone resorption.

In this study, we examined whether IL-6 stimulates IL-6 production in cultures of osteoblast-enriched cells from 22-d fetal rat calvariae (Ob cells). We also postulated that the sIL-6R potentiates this autoregulation. Since IL-6 and sIL-6R levels are increased in conditions of increased bone resorption, IL-6 autoregulation in osteoblasts may be critical for IL-6 paracrine effects on osteoclast development and bone resorption. We determined the mechanisms involved and studied the regulatory elements of the rat IL- 6 gene promoter responsible for the stimulatory effects of IL-6 and sIL-6R on IL-6 expression.

\section{Methods}

Cell culture. The culture method used was described in detail previously $(20,21)$. Parietal bones were obtained from 22 -d-old fetal rats immediately after the mothers were killed by blunt trauma to the nuchal area. This project was approved by the Animal Care and Use Committee of Saint Francis Hospital and Medical Center. Cells were obtained by five sequential digestions of the parietal bone using bacterial collagenase (CLS II; Worthington Biochemical Corp., Freehold, NJ). Cell populations harvested from the third to fifth digestions were cultured as a pool. These cells were shown previously to express osteoblastic characteristics, including the production of type I collagen, high levels of alkaline phosphatase activity and osteocalcin,

1. Abbreviations used in this paper: AP-1, activation protein-1; CMV, cytomegalovirus; CRE, cAMP responsive element; gp-80 and gp-130, 80- and 130-kD glycoproteins; MRE, multiple response element; NFIL-6, nuclear factor for IL-6; NF-кB, nuclear factor-кb; Ob cells, primary rat osteoblastic cells; sIL-6R, IL-6 soluble receptor. 
and an increase in cAMP after exposure to parathyroid hormone (22). Ob cells were plated at a density of $8,000-12,000 \mathrm{cells} / \mathrm{cm}^{2}$ and cultured in a humidified $5 \% \mathrm{CO}_{2}$ incubator at $37^{\circ} \mathrm{C}$, maintaining a $\mathrm{pH}$ of 7.5. Cells were cultured in DME supplemented with nonessential amino acids (Life Technologies, Grand Island, NY) and 10\% FBS (Summit, Fort Collins, CO). For RNA analysis, cells were grown to confluence $\left(\sim 50,000\right.$ cells $\left./ \mathrm{cm}^{2}\right)$, transferred to serum-free medium for 20-24 h, and exposed to test agents in serum-free medium for $2-48 \mathrm{~h}$, as indicated in the text and legends. For treatments lasting $48 \mathrm{~h}$, test and control cultures were replaced with fresh solutions after $24 \mathrm{~h}$. For the nuclear run-on experiment, subconfluent cultures of $\mathrm{Ob}$ cells were trypsinized, subcultured at 1:10 dilution, and grown to confluence in DME supplemented with $10 \%$ FBS. Cells were serum-deprived for $24 \mathrm{~h}$, and treated for 2 or $6 \mathrm{~h}$ in serum-free DME. For transient transfections, cells were grown to $70 \%$ confluence, transfected in $10 \%$ FBS, serum-deprived, and treated. Recombinant human IL-6 and sIL-6R (R \& D Systems, Inc., Minneapolis, MN) were dissolved in PBS containing $0.1 \%$ BSA; an equal amount of PBS containing BSA was added to control cultures. Cycloheximide (Sigma Chemical Co., St. Louis, MO) was added directly to the culture medium.

Northern blot analysis. Total cellular RNA was isolated with guanidine thiocyanate, at acid $\mathrm{pH}$, followed by phenol-chloroform (Sigma Chemical Co.) extraction, or isolated by RNeasy Kit per manufacturer's instructions (QIAGEN Inc., Chatsworth, CA) (23). RNA was precipitated with isopropanol, resuspended, and reprecipitated with ethanol. The RNA recovered was quantitated by spectrometry, and equal amounts of RNA from control or test samples were loaded on a formaldehyde agarose gel after denaturation. The gel was stained with ethidium bromide to visualize rRNA, documenting equal RNA loading of the various experimental samples. RNA was then blotted onto GeneScreen Plus charged nylon (DuPont, Wilmington, DE), and the uniformity of transfer was documented by revisualization of rRNA. A 900-bp BamHI/PstI restriction fragment of rat IL-6 cDNA, and a 700-bp BamHI/SphI fragment of a mouse 18S rRNA cDNA clone (both from American Type Culture Collection, Rockville, MD) were purified by agarose gel electrophoresis (24). IL-6 and 18S rRNA cDNAs were labeled with $\left[\alpha-{ }^{32} \mathrm{P}\right] \mathrm{dATP}$ and $\left[\alpha{ }^{32} \mathrm{P}\right] \mathrm{dCTP}(50 \mu \mathrm{Ci}$ each at a specific activity of $3,000 \mathrm{Ci} / \mathrm{mmol}$; DuPont) using the random hexanucleotide primed second-strand synthesis method (25). Hybridizations were carried out at $42^{\circ} \mathrm{C}$ for $16-48 \mathrm{~h}$, and posthybridization washes were performed at $65^{\circ} \mathrm{C}$ in $1 \times \mathrm{SSC}$. The bound radioactive material was visualized by autoradiography on X-AR5 film (Eastman Kodak Co., Rochester, NY), employing Cronex Lightning Plus intensifying screens (DuPont). Relative hybridization levels were determined by densitometry. Northern blot analyses shown are representative of three or more cultures.

Nuclear run-on assay. To examine changes in the rate of transcription, nuclei were isolated by Dounce homogenization in a Tris buffer, $\mathrm{pH} 7.4$, containing $0.5 \%$ NP-40 (26). Nascent transcripts were labeled by incubation of nuclei in a reaction buffer containing $500 \mu \mathrm{M}$ each ATP, CTP, and GTP, 150 U RNasin (Promega Corp., Madison, WI), and $250 \mu \mathrm{Ci}\left[\alpha{ }^{32} \mathrm{P}\right] \mathrm{UTP}(3,000 \mathrm{Ci} / \mathrm{mmol}$; DuPont) (27). RNA was isolated by treatment with DNase I and proteinase K, followed by phenol-chloroform extraction and ethanol precipitation. Linearized plasmid DNA containing $\sim 1 \mu \mathrm{g}$ cDNA was immobilized onto GeneScreen Plus by slot blotting according to manufacturer's directions (DuPont). The plasmid vector pGL2-Basic (Promega Corp.) was used as a control for nonspecific hybridization, and a mouse $18 \mathrm{~S}$ rRNA cDNA clone was used to estimate uniformity of the loading. Equal counts per minute of ${ }^{32} \mathrm{P}$-RNA from each sample were hybridized to cDNAs at $42^{\circ} \mathrm{C}$ for $72 \mathrm{~h}$ and washed in $1 \times \mathrm{SSC}$ at $65^{\circ} \mathrm{C}$ for 20 min. Hybridized cDNAs were visualized by autoradiography, and IL-6 hybridization levels were determined by densitometry.

Transient transfections. To determine changes in promoter activity, chimeric constructs of the 5' flanking region of the IL-6 promoter and the luciferase reporter gene (kindly provided by Dr. G. Fey, Friedrich-Alexander Universität, Erlangen, Germany) were tested (28). Ob cells were cultured to $\sim 70 \%$ confluence and transiently transfected by calcium phosphate-DNA coprecipitation as described (29). A construct containing the cytomegalovirus (CMV) promoterdriven $\beta$-galactosidase gene (Clontech, Palo Alto, CA) was used to control for transfection efficiency. After $4 \mathrm{~h}$, cells were exposed for 3 min to $10 \%$ glycerol. Ob cells were allowed to recover in serum-containing DME for $24 \mathrm{~h}$, serum-deprived for 20-24 h, and exposed to control or test medium for 6-24 h as described in text and legends. Cells were washed with PBS and harvested in reporter lysis buffer (Promega Corp.). Luciferase activity was measured using a luciferase assay kit (Promega Corp.), and $\beta$-galactosidase activity was measured using Galacton reagent (Tropix, Inc., Bedford, MA), both in accordance with manufacturer's instructions. Luciferase activity was corrected for $\beta$-galactosidase activity, and data were expressed as treated/ control ratios. Data are presented as means \pm SEM. Statistical differences were determined by ANOVA and post hoc examination by Ryan-Einot-Gabriel-Welsh F test $(30,31)$.

Site-directed mutagenesis. Site-directed mutagenesis was performed using the method of gene splicing by overlap extension or by using the Morph Mutagenesis Kit (5 Prime $\rightarrow 3$ Prime, Inc., Boulder, CO) (32). The Morph Mutagenesis Kit was used in accordance with manufacturer's instructions to create targeted mutations of the multiple response element (MRE)/cAMP responsive element (CRE) and of the nuclear factor for IL-6 (NF-IL-6), alone or in combination (Fig. 1). Gene splicing by overlap extension was used to create mutations of the nuclear factor-кB (NF-кB), alone or in combination with NF-IL-6 (double mutation) or with MRE/CRE and NF-IL-6 (triple mutation). For this purpose, wild-type and mutant constructs were generated by PCR using a 5' primer containing a SacI restriction site on the 5' end and the sequence corresponding to bp -257 to -249 of the rat IL-6 promoter (5'-AGGCGAGCTCAAAGAAAGA-3'), in the presence of a $3^{\prime}$ primer corresponding to $\mathrm{bp}+6$ to +20 of the rat IL- 6 gene that included an XhoI restriction site on the $3^{\prime}$ end (5'-CCGCTCGAGACAGAATGA-3'). A chimeric construct containing bp -257 to +20 of the IL-6 promoter was used as a template. Mutant sense and antisense primers, used to synthesize the intermediate products, contained nucleotide sequences corresponding to the known consensus sequences of the binding sites with two or three altered bases, creating the desired targeted mutations (Fig. 1). Targeted multiple mutations of NF-IL-6 and NF- $\mathrm{BB}$ (double mutation) or MRE/CRE, NFIL-6, and NF- $\mathrm{kB}$ (triple mutation) were generated by PCR using mutant sense and antisense primers for NF- $\mathrm{KB}$ in the presence of the

1. Targeted mutations of MRE and NF-IL- 6 binding sites

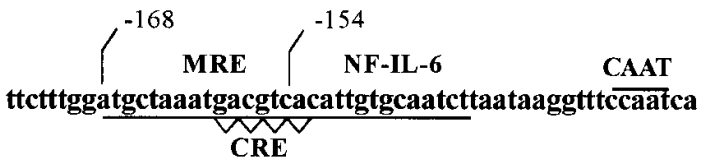

$5^{\prime}$ gatgctaaatCCTgtcacattgtgca $3^{\prime}$

5' cacattgtgcaGGAttaataaggttt 3 '

5' gatgctaaatCCTgtcacattgtgcaGGAttaataaggttt 3'

2. Targeted mutation of NF-kB binding site

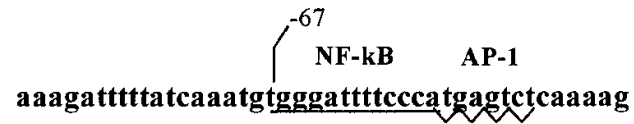

5 ' caaatgtgggat $C$ Ctcccatgagtct 3 '

Figure 1. Oligonucleotides used for targeted mutation analysis of the IL-6 gene. Bold, Wild-type sequence of the IL-6 promoter. Capital letters within the primers indicate mutations used to alter the sequence of MRE/CRE, NF-IL-6, and NF- $\mathrm{B}$ binding sites. 
Figure 2. Effect of IL-6 at 100 and sIL-6R $(s R)$ at $125 \mathrm{ng} / \mathrm{ml}$, singly treated for 2-48 h. Total RNA from control or treated cells was subjected to Northern blot analysis and hybridized with an $\left[\alpha-{ }^{32} \mathrm{P}\right]-$ labeled IL-6 cDNA. IL-6 transcripts of 1.2 and $2.4 \mathrm{~kb}$ were visualized by autoradiography. Blots were stripped and rehybridized with an $\left[\alpha{ }^{32} \mathrm{P}\right]$-labeled $18 \mathrm{~S}$ rRNA cDNA. Upper panel, IL-6 transcripts. Lower panel, 18S rRNA transcripts.

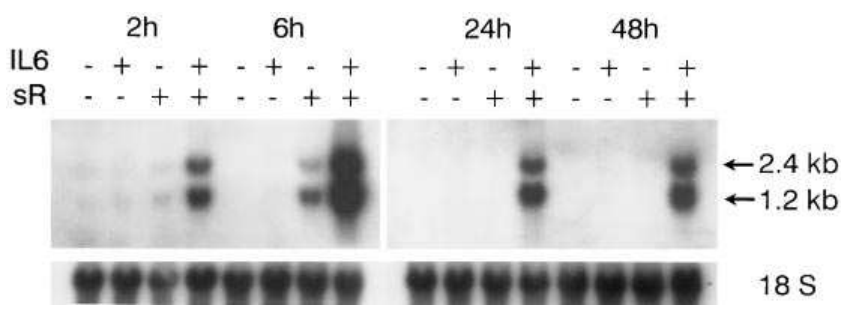
and in combination, on IL- 6 mRNA levels in cultures of Ob cells
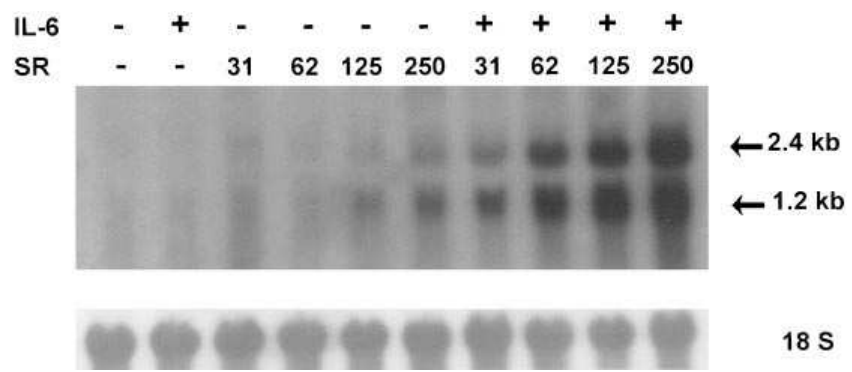

$18 \mathrm{~S}$

Figure 4. Effect of sIL-6R $(S R)$ at $31-250 \mathrm{ng} / \mathrm{ml}$ in the presence $(+)$ or absence (-) of IL-6 on IL-6 mRNA levels in cultures of Ob cells treated for $6 \mathrm{~h}$. Total RNA from control, IL-6-, or sIL-6R-treated cells was subjected to Northern blot analysis and hybridized with an $\left[\alpha-{ }^{32} \mathrm{P}\right]$-labeled IL-6 cDNA. IL-6 transcripts of 1.2 and $2.4 \mathrm{~kb}$ were visualized by autoradiography. Blots were stripped and rehybridized with an $\left[\alpha{ }^{32} \mathrm{P}\right]$-labeled $18 \mathrm{~S}$ rRNA cDNA. Upper panel, IL-6 transcripts. Lower panel, 18S rRNA transcripts.

NF-IL-6 or MRE/CRE and NF-IL-6 mutated constructs as a template. Newly synthesized wild-type and target-mutated IL-6 promoter fragments were cloned into pGL-3 Basic (Promega Corp.) containing a luciferase reporter gene. Sequences of the wild-type and mutated constructs generated by either the Morph Mutagenesis Kit or PCR were confirmed by DNA sequence analysis using the Sequenase Version 2.0 DNA sequencing kit (United States Biochemical Corp., Cleveland, $\mathrm{OH})$.

\section{Results}

Northern blot analysis of total RNA from serum-deprived confluent $\mathrm{Ob}$ cells revealed limited expression of a 1.2- and a 2.4-kb IL-6 transcript. IL-6 by itself did not induce IL-6 transcripts, but in the presence of sIL-6R, IL-6 caused a time- and dose-dependent stimulation of IL-6 mRNA levels (Figs. 2 and 3). IL-6 at $100 \mathrm{ng} / \mathrm{ml}$ in the presence of sIL-6R at $125 \mathrm{ng} / \mathrm{ml}$ induced IL-6 mRNA levels after $2 \mathrm{~h}$; the effect was maximal after $6 \mathrm{~h}$, and was sustained for 24-48 h (Fig. 2). In the presence of sIL-6R, the effect of IL-6 was observed at concentrations of $1-300 \mathrm{ng} / \mathrm{ml}$ (Fig. 3). sIL-6R at 31-250 ng/ml also caused a dosedependent induction of IL-6 mRNA, and this effect was ob-

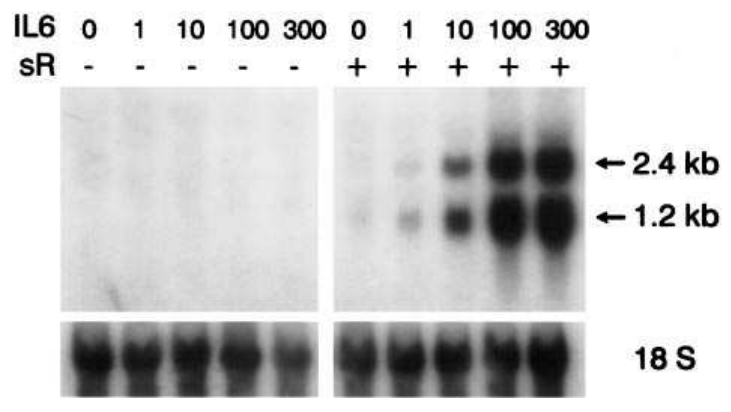

Figure 3. Effect of IL-6 at $1-300 \mathrm{ng} / \mathrm{ml}$ in the presence $(+)$ and absence $(-)$ of sIL-6R $(s R)$ at $125 \mathrm{ng} / \mathrm{ml}$ on IL-6 mRNA levels in cultures of Ob cells treated for $6 \mathrm{~h}$. Total RNA from control, IL-6-, or sIL-6R-treated cells was subjected to Northern blot analysis and hybridized with an $\left[\alpha{ }^{-32} \mathrm{P}\right]$-labeled IL- 6 cDNA. IL- 6 transcripts of 1.2 and $2.4 \mathrm{~kb}$ were visualized by autoradiography. Blots were stripped and rehybridized with an $\left[\alpha-{ }^{32} \mathrm{P}\right]$-labeled $18 \mathrm{~S}$ rRNA cDNA. Upper panel, IL-6 transcripts. Lower panel, 18S rRNA transcripts. served in the presence and absence of IL-6 at $100 \mathrm{ng} / \mathrm{ml}$ (Fig. 4). To determine whether the autoregulation of IL-6 was dependent on protein synthesis, Ob cells were treated for $6 \mathrm{~h}$ with IL-6 at 100 and sIL-6R at $125 \mathrm{ng} / \mathrm{ml}$ in the presence or absence of the protein synthesis inhibitor cycloheximide at $3.6 \mu \mathrm{M}$. Cycloheximide superinduced IL- 6 mRNA levels and did not prevent the effect of IL-6 and sIL-6R (Fig. 5).

To analyze the mechanisms involved in the autoregulation of IL-6, we examined the effects of IL- 6 and sIL-6R on the rate of transcription of the IL- 6 gene by a nuclear run-on assay performed on nuclei from $\mathrm{Ob}$ cells exposed to control medium or to IL- 6 at 100 and sIL-6R at $50 \mathrm{ng} / \mathrm{ml}$ for 2 and $6 \mathrm{~h}$. After $6 \mathrm{~h}$, IL-6 in the presence of sIL-6R increased IL-6 transcription rates 2-2.5-fold, demonstrating a transcriptional effect (Fig. 6).

To confirm that IL-6 autoregulation occurs by transcriptional mechanisms, and to define gene elements responsible for the effect, $\mathrm{Ob}$ cells were transfected transiently with chimeric constructs containing fragments of the IL-6 promoter linked to the reporter gene luciferase. The effects of IL-6 at 100 and sIL-6R at $125 \mathrm{ng} / \mathrm{ml}$ alone or in combination were tested for 6-24 h on a bp -2906 to +20 fragment of the rat IL-6 promoter. IL- 6 or sIL-6R alone caused a small, for the most

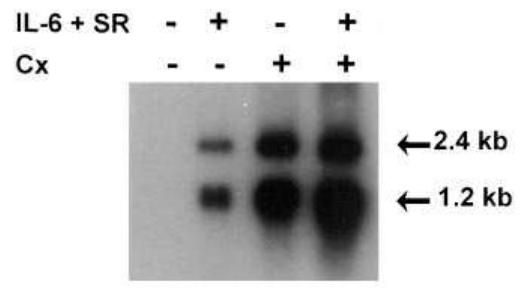

Figure 5. Effect of IL-6 at 100 and sIL-6R $(S R)$ at $125 \mathrm{ng} / \mathrm{ml}$ in the presence $(+)$ or absence $(-)$ of cycloheximide $(C x)$ at $3.6 \mu \mathrm{M}$ on IL-6 mRNA levels in cultures of $\mathrm{Ob}$ cells treated for $6 \mathrm{~h}$. Total RNA

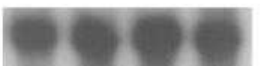

$18 \mathrm{~S}$ from control, cycloheximide-, or IL-6 + sIL6R-treated cells was subjected to Northern blot analysis and hybridized with an $\left[\alpha-{ }^{32} \mathrm{P}\right]-$ labeled IL- 6 cDNA. IL-6 transcripts of 1.2 and $2.4 \mathrm{~kb}$ were visualized by autoradiography. Blots were stripped and rehybridized with an $\left[\alpha-{ }^{32} \mathrm{P}\right]$-labeled 18S rRNA cDNA. Upper panel, IL-6 transcripts. Lower panel, $18 \mathrm{~S}$ rRNA transcripts. part not statistically significant, stimulatory effect on promoter 


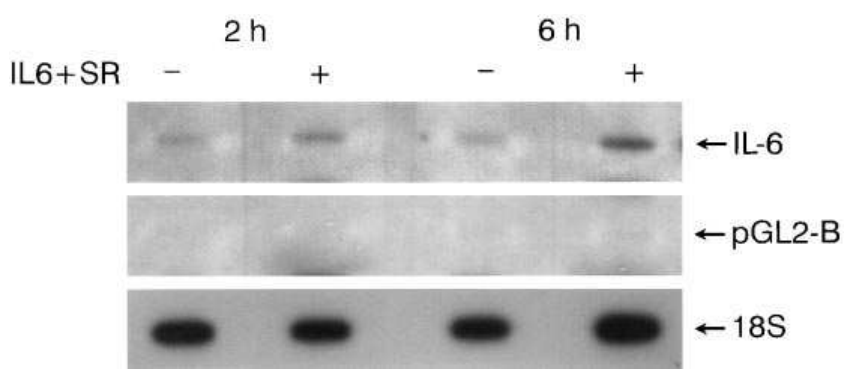

Figure 6. Effect of IL-6 at $100 \mathrm{ng} / \mathrm{ml}$ in the presence of sIL-6R (SR) at $50 \mathrm{ng} / \mathrm{ml}$ on IL-6 transcription rates in cultures of Ob cells treated for 2 and $6 \mathrm{~h}$. Nascent transcripts from control (-) or IL-6- and sIL-6R $(+)$-treated cultures were labeled in vitro with $\left[\alpha-{ }^{32} \mathrm{P}\right] \mathrm{UTP}$, and the labeled RNA was hybridized to immobilized cDNA for IL-6. 18S rRNA cDNA was used to demonstrate loading, and pGL2-Basic vector DNA was used as a control for nonspecific hybridization.

activity (Fig. 7). However, IL-6 at $100 \mathrm{ng} / \mathrm{ml}$, in the presence of sIL-6R at $125 \mathrm{ng} / \mathrm{ml}$, caused an eightfold increase in promoter activity after $6 \mathrm{~h}$, and a 13-16-fold stimulation after 16 and $24 \mathrm{~h}$ (Figs. 7 and 8). To characterize the regulatory elements involved, 5' deletion constructs of the IL-6 promoter ranging from bp -2906 to +20 to bp -34 to +20 were tested in six different experiments. $5^{\prime}$ deletions from bp -2906 to -257 of the IL-6 promoter resulted in a decrease in the basal activity of the IL-6 promoter (not shown), but did not preclude the response to IL- 6 in the presence of sIL-6R. IL- 6 with sIL-6R induced the bp -276 to +20 and the bp -257 to +20 of the IL- 6 pro-

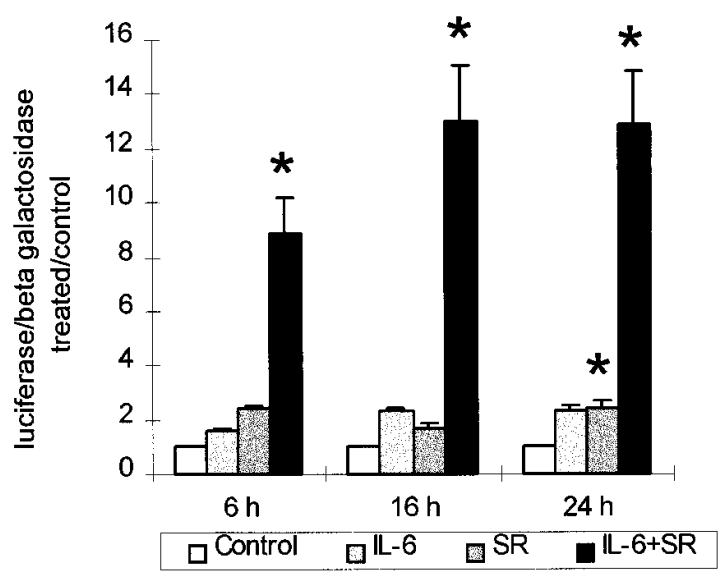

Figure 7. Effect of IL-6 at 100 and sIL-6R (SR) at $125 \mathrm{ng} / \mathrm{ml}$, singly and in combination, on IL-6 promoter activity in transiently transfected $\mathrm{Ob}$ cells. Ob cells were transfected with $35 \mu \mathrm{g}$ DNA of a chimeric construct containing the rat IL-6 promoter sequence of bp -2906 to +20 linked to a luciferase reporter gene by calcium phosphate-DNA coprecipitation. To control for transfection efficiency, $10 \mu \mathrm{g}$ of a CMV- $\beta$-galactosidase expression vector was cotransfected. $24 \mathrm{~h}$ after transfection, $\mathrm{Ob}$ cells were serum-deprived for $20-24 \mathrm{~h}$ and exposed to IL-6 or sIL-6R singly and in combination for the indicated periods of time. Cells were harvested, and luciferase activity was determined, corrected for $\beta$-galactosidase activity, and expressed as treated/control ratios for each individual time period studied. Values are means \pm SEM of 18-24 observations pooled from four independent experiments; SEM not shown were too small to be depicted. *Significantly different from control $(P<0.05)$.
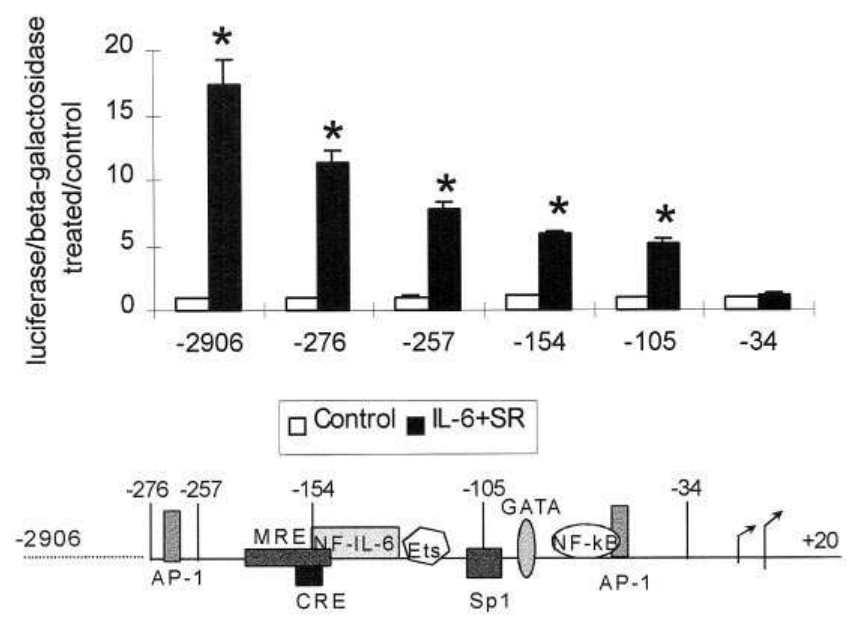

Figure 8. Effect of IL-6 at $100 \mathrm{ng} / \mathrm{ml}$, in the presence of sIL-6R $(S R)$ at $125 \mathrm{ng} / \mathrm{ml}$, on IL-6 promoter activity in transiently transfected $\mathrm{Ob}$ cells. Ob cells were transfected with $35 \mu \mathrm{g}$ DNA of chimeric constructs containing fragments of the IL-6 promoter linked to a luciferase reporter gene by calcium phosphate-DNA coprecipitation. The $5^{\prime}$ deletion endpoints of the IL-6 promoter are indicated (bottom). To control for transfection efficiency, $10 \mu \mathrm{g}$ of a CMV- $\beta$-galactosidase expression vector was cotransfected. $24 \mathrm{~h}$ after transfection, $\mathrm{Ob}$ cells were serum-deprived for 20-24 $\mathrm{h}$ and exposed to IL-6 in the presence of sIL-6R for $16 \mathrm{~h}$. Cells were harvested and analyzed, and luciferase activity was determined, corrected for $\beta$-galactosidase activity, and expressed as treated/control ratios for each construct tested. Values are means \pm SEM of 22-33 observations, pooled from six independent experiments; SEM not shown were too small to be depicted. *Significantly different from respective control $(P<0.05)$. (Bottom) Putative cis-regulatory elements of the rat IL-6 promoter with their approximate locations relative to the major start site. Bars, $5^{\prime}$ deletion points of the truncated constructs used.

moter construct by 11- and 8-fold, respectively. In individual experiments, we were unable to detect consistent differences in the response of these two constructs. Deletion to bp -154 and to bp -105 resulted in a partial loss of the stimulatory effect of IL-6 and its soluble receptor, and together they increased the activity of the two constructs five- to sixfold (Fig. 8 ). The basal activity of the bp -34 to +20 IL-6 promoter fragment was decreased dramatically (not shown), and IL-6, with sIL-6R, did not modify the activity of this construct. These results suggest that MRE/CRE, NF-IL-6, and NF- $\mathrm{B}$ binding sites contained in the bp -257 to +20 region of the IL- 6 gene are potentially necessary for the response to IL-6 and sIL-6R.

To define the elements responsible for the autoregulation of IL- 6 , a bp -257 to +20 fragment of the IL- 6 promoter was cloned into pGL-3 Basic, and targeted mutations of the known consensus sequences of MRE/CRE, NF-IL-6, and NF-kB binding sites were made singly or in combination and tested in two separate experiments, which revealed analogous results. In the experiment shown in Fig. 9, IL-6 and sIL-6R increased the activity of the bp -257 to +20 wild-type IL- 6 construct sixfold. Targeted single mutations of NF-IL-6, NF-кB, or MRE/ CRE binding sites resulted in a decrease in the response to IL-6 and its soluble receptor (all $P<0.05$ vs. wild-type). The combined NF-IL-6 and NF-кB or MRE/CRE and NF-IL-6 mutations resulted in a comparable decrease in the response to IL-6 


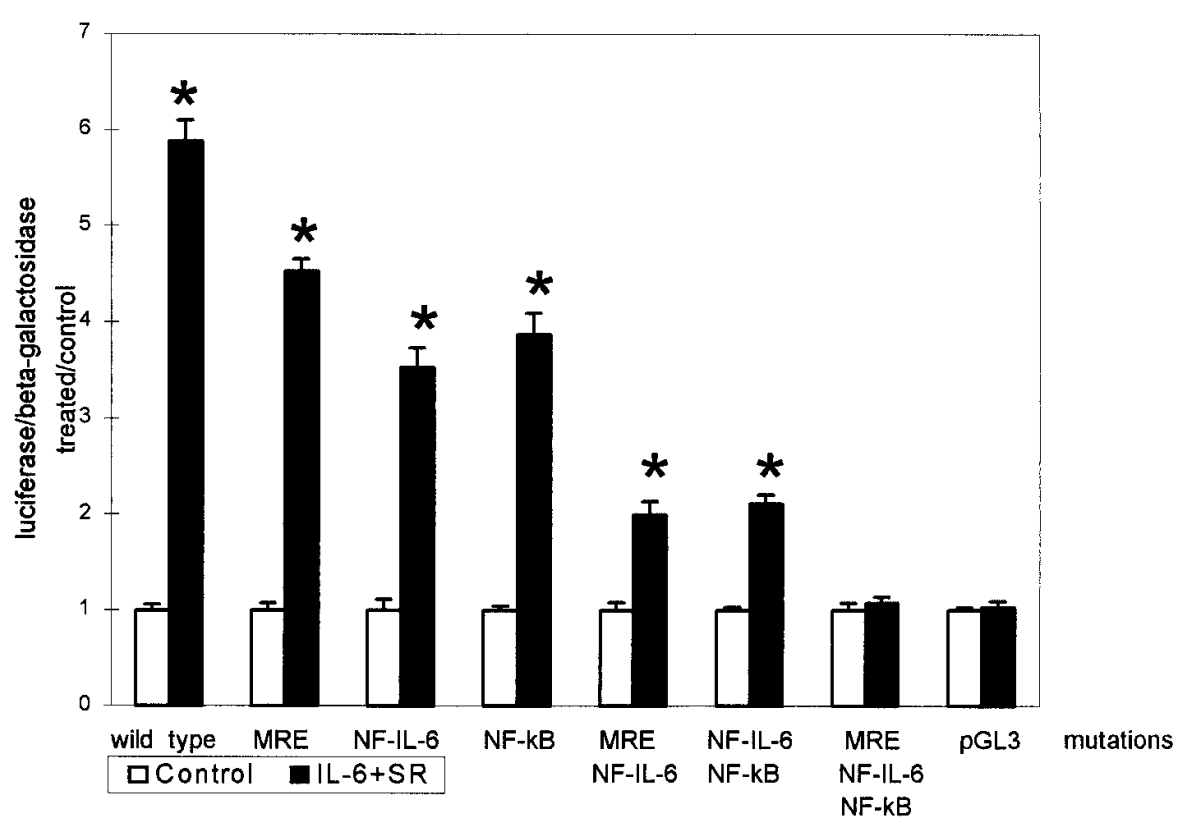

Figure 9. Effect of IL-6 at $100 \mathrm{ng} / \mathrm{ml}$, in the presence of sIL-6R $(S R)$ at $125 \mathrm{ng} / \mathrm{ml}$, on IL-6 promoter activity in transiently transfected $\mathrm{Ob}$ cells. Ob cells were transfected with $35 \mu \mathrm{g}$ of a chimeric construct containing a bp -257 to +20 fragment of the IL- 6 promoter, with or without mutations of MRE, NF-IL-6, and NF-кB alone or mutations of the combinations MRE and NF-IL-6, NF-IL-6 and NF- $\kappa$ B, and MRE, NF-IL-6, and NF-кB. Constructs were linked to a luciferase reporter gene and transfected by calcium phosphate-DNA coprecipitation. To control for transfection efficiency, $10 \mu \mathrm{g}$ of a CMV- $\beta$-galactosidase expression vector was cotransfected. $24 \mathrm{~h}$ after transfection, $\mathrm{Ob}$ cells were serum-deprived for 20-24 $\mathrm{h}$ and exposed to IL-6 in the presence of sIL-6R for $16 \mathrm{~h}$. Cells were harvested, and luciferase activity was determined, corrected for $\beta$-galactosidase activity, and expressed as treated/ control ratios for each construct tested. Values are means \pm SEM of six observations. *Significantly different from control $(P<0.05)$. and sIL-6R, which was more pronounced than the decrease observed with single mutations $(P<0.05)$. The triple mutation of MRE/CRE, NF-IL-6, and NF- $\mathrm{KB}$ resulted in a total loss of the IL-6 promoter response to IL- 6 and sIL-6R ( $P<0.05$ vs. wild-type, and all constructs with single or double mutations).

\section{Discussion}

In these studies, we have demonstrated that IL-6 in the presence of its soluble receptor induces IL- 6 mRNA in Ob cells. Although IL- 6 has been shown to induce IL- 6 mRNA in the osteoblastic cells MC3T3-E1, the effect was small and only detected by reverse transcription-PCR (33). The lack of an IL-6 effect when tested alone is probably due to the low level of expression of the membrane-bound IL-6 receptor in Ob cells or due to receptor downregulation. IL- 6 binds an $80-\mathrm{kD}$ surface glycoprotein, and the IL-6/surface receptor complex associates with gp-130 molecules, which activate the JAK/STAT signal transduction pathway (34). A soluble form of the IL-6 receptor is present in human and mouse serum and was found to enhance the effects of IL-6 in various cell types, including osteoclasts $(12,17,35)$. Similarly, we showed that the effects of IL-6 on IL-6 transcripts in Ob cells were observed in the presence of its soluble receptor. Moreover, increasing concentrations of sIL-6R induced IL-6 transcripts in the absence of exogenous IL-6, suggesting that endogenous IL-6 is produced in sufficient amounts to induce its own synthesis in the presence of its soluble receptor.

The sIL-6R is a $55-\mathrm{kD}$ protein generated by proteolytic cleavage of the membrane-bound receptor at a site adjacent to the transmembrane domain, or by translation of an alternatively spliced RNA $(13-15,36,37)$. The sIL-6R binds IL-6 with similar affinity as the membrane-bound receptor, and the complex can elicit IL-6 signaling in cells that do not express cell surface-associated receptor, provided that they express gp-130
(14). This indicates that the sIL-6R is sufficient to mediate IL-6 action. sIL-6R can be measured in human serum, and elevated levels are associated with conditions of increased bone resorption, such as multiple myeloma or estrogen deficiency $(18,19)$. However, it is not known whether or not osteoblasts or other cells present in the bone environment produce sIL-6R. The concentrations of sIL-6R used in these studies are similar to those found in serum, suggesting that the amplification of the IL-6 effect by its soluble receptor is physiologically or pathologically relevant.

To study the mechanisms of IL- 6 stimulation of its own synthesis, we tested the effect of the protein synthesis inhibitor cycloheximide. As previously described, cycloheximide superinduced IL-6 transcripts, suggesting stabilization of IL-6 mRNA (38). In the presence of cycloheximide, IL-6 and sIL-6R had an additive effect on IL- 6 mRNA levels, demonstrating that IL-6 autoregulation is not protein synthesis dependent. In addition, we have shown that the autoregulation of IL-6 occurs at the transcriptional level, since IL-6 in the presence of sIL-6R enhanced IL- 6 rates of transcription and promoter activity. Using $5^{\prime}$ deletion constructs, we demonstrated that a bp -257 to +20 fragment of the IL-6 promoter is responsive to IL-6 and sIL-6R. The -257 to +20 region of the IL- 6 gene contains important sequences, including MRE/CRE, NF-IL-6, and $\mathrm{NF}-\kappa \mathrm{B}$ binding sites, and these sequences are essential for the response of IL-6 to IL-1 and TNF- $\alpha(39,40)$. In hepatocytes, IL-6 increases NF-IL-6 mRNA levels and NF-IL-6 binding activity $(40,41)$. In this study, we demonstrated that an NF-IL-6 binding site is necessary for the response of the IL- 6 promoter to IL-6, but mutation of the NF-IL-6 binding site was not sufficient to abolish the response to IL-6. Even though experiments using $5^{\prime}$ deletion constructs indicated that MRE/CRE or $\mathrm{NF} \kappa \mathrm{B}$ binding sites are involved in the response to IL- 6 and its soluble receptor, single targeted mutations of MRE/CRE or $\mathrm{NF} * \mathrm{~B}$ did not abrogate the response of the IL- 6 promoter. When NF- 
IL-6 and NF-кB binding sites were mutated in combination, the response of the IL- 6 promoter to IL- 6 and sIL-6R was decreased further, and when all three binding sites were mutated, no response to IL-6 and sIL-6R was observed. These results indicate that MRE/CRE, NF-IL-6, and NF-кB could operate synergistically, an observation supported by previous work demonstrating that both NF-IL-6 and NF- $\mathrm{BB}$ binding sites are required for the regulation of immune and acute-phase response genes such as the IL-6 gene (42). Similar to our results, prostaglandin and cAMP activation of the IL- 6 gene require MRE, NF-IL-6, and NF-кB binding sites as well as an activation protein-1 (AP-1) binding site (43). In this study, we were unable to detect consistent differences in the response of the bp -276 to +20 and $b p-257$ to +20 construct to IL-6 and sIL$6 \mathrm{R}$, indicating that the AP- 1 site located at bp -263 to -269 of the IL-6 promoter probably does not play a central role in the autoregulation of IL- 6 in osteoblasts. Additional regulatory binding sites upstream of bp -276 may be required for the IL-6 promoter response to IL- 6 and sIL-6R, since deletions from bp -2906 to -276 resulted in a decrease in the response to IL-6 and sIL-6R.

In conclusion, IL-6 synthesis is autoinduced in osteoblastic cells by transcriptional mechanisms, an effect that requires the presence of sIL-6R. IL-6 autoregulation may play a central role in the effects of IL- 6 on bone resorption.

\section{Acknowledgments}

The authors thank Dr. G. Fey for providing IL-6 promoter constructs, Cathy Boucher, Bari Gabbitas, and Deena Durant for technical assistance, and Mrs. Margaret Nagle for secretarial help.

This work was supported by grant AR-21707 from the National Institute of Arthritis and Musculoskeletal and Skin Diseases, National Institutes of Health. Dr. N. Franchimont was supported by a fellowship award from the Catherine Weldon Donaghue Foundation.

\section{References}

1. Roodman, G.D. 1992. Interleukin-6: an osteotropic factor? J. Bone Miner. Res. 7:475-478.

2. Löwik, C.W.G.M. 1992. Differentiation inducing factors: leukemia inhibitory factor and interleukin-6. In Cytokines and Bone Metabolism. M. Gowen, editor. CRC Press, Inc., London. 299-324.

3. Kurihara, N., C. Civin, and G.D. Roodman. 1991. Osteotropic factor responsiveness of highly purified populations of early and late precursors for human multinucleated cells expressing the osteoclast phenotype. J. Bone Miner. Res. 6:257-261.

4. Feyen, J.H., P. Elford, F.E. Di Padova, and U. Trechsel. 1989. Interleukin-6 is produced by bone and modulated by parathyroid hormone. J. Bone Miner. Res. 4:633-638.

5. Franchimont, N., Y. Vrindts, S. Gaspar, M. Lopez, R. Gathy, D. DeGroote, J.Y. Reginster, and P. Franchimont. 1993. Parathyroid hormone (1-34) stimulates and $1,25(\mathrm{OH})_{2}$ vitamin $\mathrm{D}_{3}$ inhibits leukemia inhibitory factor (LIF) production by osteoblasts in vitro. In Proceedings 1993: Fourth International Symposium on Osteoporosis and Consensus Development Conference. C. Christiansen and B. Riis, editors. Handelstrykkeriet Aalborg ApS, Aalborg, Denmark. 249-250.

6. Helle, M., J.P.J. Brakenhoff, E.R. DeGroot, and L.A. Aarden. 1988. Interleukin-6 is involved in interleukin-1 induced activities. Eur. J. Immunol. 18: 957-959.

7. Littlewood, A.J., J. Russell, G.R. Harvey, D.E. Hughes, R.G.G. Russell, and M. Gowen. 1991. The modulation of the expression of IL-6 and its receptor in human osteoblasts in vitro. Endocrinology. 129:1513-1520.

8. Jilka, R.L., G. Hangoc, G. Girasole, G. Passeri, D.C. Williams, J.S. Abrams, B. Boyce, H. Broxmeyer, and S.C. Manolagas. 1992. Increased osteoclast development after estrogen loss: mediation by interleukin-6. Science (Wash. DC). 257:88-91.

9. Kawano, M., T. Hirano, T. Matsuda, T. Taga, Y. Horii, K. Iwato, H. Asaoku, B. Tang, O. Tanabe, H. Tanaka, et al. 1988. Autocrine generation and requirement of BSF-2/IL-6 for human multiple myeloma. Nature (Lond.). 332:
$83-85$.

10. Klein, B., X.G. Zhang, Z.Y. Lu, and R. Bataille. 1995. Interleukin-6 in human multiple myeloma. Blood. 85:863-872.

11. Bataille, R., D. Chappard, and B. Klein. 1992. The critical role of interleukin-6, interleukin-1B and macrophage colony-stimulating factor in the pathogenesis of bone lesions in multiple myeloma. Int. J. Clin. Lab. Res. 21: 283-287.

12. Tamura, T., N. Udagawa, N. Takahashi, C. Miyaura, S. Tanaka, Y. Yamada, Y. Koishihara, Y. Ohsugi, K. Kumaki, T. Taga, et al. 1993. Soluble interleukin-6 receptor triggers osteoclast formation by interleukin 6. Proc. Natl. Acad. Sci. USA. 90:11924-11928.

13. Müllberg, J., H. Schooltink, T. Stoyan, M. Günther, L. Graeve, G. Buse, A. Mackiewicz, P.C. Heinrich, and S. Rose-John. 1993. The soluble interleukin-6 receptor is generated by shedding. Eur. J. Immunol. 23:473-480.

14. Rose-John, S., M. Ehlers, J. Grötzinger, and J. Müllberg. 1995. The soluble interleukin-6 receptor. Ann. NY Acad. Sci. 762:207-221.

15. Lust, J.A., K.A. Donovan, M.P. Kline, P.R. Greipp, R.A. Kyle, and N.J. Maihle. 1992. Isolation of an mRNA encoding a soluble form of the human interleukin-6 receptor. Cytokine. 4:96-100.

16. Taga, T., M. Hibi, Y. Hirata, K. Yamasaki, K. Yasukawa, T. Matsuda, T. Hirano, and T. Kishimoto. 1989. Interleukin-6 triggers the association of its receptor with a possible signal transducer, gp130. Cell. 58:573-581.

17. Frieling, J.T.M., R.W. Sauerwein, J. Wijdenes, T. Hendriks, and C.J. van der Linden. 1994. Soluble interleukin 6 receptor in biological fluids from human origin. Cytokine. 6:376-381.

18. Gaillard, J.-P., R. Bataille, H. Brailly, C. Zuber, K. Yasukawa, M. Attal, N. Maruo, T. Taga, T. Kishimoto, and B. Klein. 1993. Increased and highly stable levels of functional soluble interleukin-6 receptor in sera of patients with monoclonal gammopathy. Eur. J. Immunol. 23:820-824.

19. Girasole, G., M. Pedrazzoni, N. Giuliani, G. Passeri, and M. Passeri. 1995. Increased serum soluble interleukin-6 receptor levels are induced by ovariectomy, prevented by estrogen replacement and reversed by alendronate administration. J. Bone Miner. Res.10:S160. (Abstr.)

20. Centrella, M., T.L. McCarthy, W.F. Kusmik, and E. Canalis. 1991. Relative binding and biochemical effects of heterodimeric and homodimeric isoforms of platelet-derived growth factor in osteoblast-enriched cultures from fetal rat bone. J. Cell. Physiol. 147:420-426.

21. Centrella, M., T.L. McCarthy, and E. Canalis. 1989. Platelet-derived growth factor enhances deoxyribonucleic acid and collagen synthesis in osteoblast-enriched cultures from fetal rat parietal bone. Endocrinology. 125:13-19.

22. McCarthy, T.L., M. Centrella, and E. Canalis. 1988. Further biochemical and molecular characterization of primary rat parietal bone cell cultures. $J$. Bone Miner. Res. 3:401-408.

23. Chomczynski, P., and N. Sacchi. 1987. Single-step method of RNA isolation by acid guanidinium thiocyanate-phenol-chloroform extraction. Anal. Biochem. 162:156-159.

24. Northemann, W., T.A. Braciak, M. Hattori, F. Lee, and G.H. Fey. 1989. Structure of the rat interleukin 6 gene and its expression in macrophage-derived cells. J. Biol. Chem. 264:16072-16082.

25. Feinberg, A.P., and B. Vogelstein. 1984. A technique for radiolabeling DNA restriction endonuclease fragments to high specific activity. Anal. Biochem. 137:266-267.

26. Ausubel, F.M., R. Brent, R.E. Kingston, D.D. Moore, J.G. Seidman, J.A. Smith, and K. Struhl. 1995. Preparation and analysis of RNA. In Current Protocols in Molecular Biology. John Wiley \& Sons Inc., New York. 4.10.5-4.10.9.

27. Greenberg, M.E., and E.B. Ziff. 1984. Stimulation of 3 T3 cells induces transcription of the c-fos proto-oncogene. Nature (Lond.). 311:433-438.

28. Baffet, G., T.A. Braciak, R.G. Fletcher, J. Gauldie, G.H. Fey, and W. Northemann. 1991. Autocrine activity of interleukin 6 secreted by hepatocarcinoma cell lines. Mol. Biol. Med. 8:141-156.

29. Pash, J.M., A.M. Delany, M.L. Adamo, C.T. Roberts, Jr., D. LeRoith, and E. Canalis. 1995. Regulation of insulin-like growth factor I transcription by prostaglandin $\mathrm{E}_{2}$ in osteoblast cells. Endocrinology. 136:33-38.

30. Godfrey, K. 1985. Statistics in practice. Comparing the means of several groups. N. Engl. J. Med. 313:1450-1456.

31. Wall, F.J. 1986. Statistical Data Analysis Handbook. McGraw-Hill Inc., New York.

32. Horton, R.M. 1993. In vitro recombination and mutagenesis of DNA SOEing together tailor-made genes. In Methods in Molecular Biology, Volume 15. B.A. White, editor. Humana Press Inc., Totowa, NJ. 251-261.

33. Greenfield, E.M., S.M. Shaw, S.A. Gornik, and M.A. Banks. 1995. Adenyl cyclase and interleukin 6 are downstream effectors of parathyroid hormone resulting in stimulation of bone resorption. J. Clin. Invest. 96:1238-1244.

34. Bellido, T., N. Stahl, T.J. Farruggella, V. Borba, G.D. Yancopoulos, and S.C. Manolagas. 1996. Detection of receptors for interleukin 6, interleukin 11, leukemia inhibitory factor, oncostatin $\mathbf{M}$, and ciliary neurotrophic factor in bone marrow stromal/osteoblastic cells. J. Clin. Invest. 97:431-437.

35. Suzuki, H., K. Yasukawa, T. Saito, M. Narazaki, A. Hasegawa, T. Taga, and T. Kishimoto. 1993. Serum soluble interleukin-6 receptor in MRL/1pr mice is elevated with age and mediates the interleukin-6 signal. Eur. J. Immunol. 23: 1078-1082.

36. Heinrich, P.C., L. Graeve, S. Rose-John, J. Schneider-Mergener, E. Dit- 
trich, A. Erren, C. Gerhartz, H. Ulrike, C. Lütticken, U. Wegenka, et al. 1995. Membrane-bound and soluble interleukin-6 receptor: studies on structure, regulation of expression, and signal transduction. Ann. NY Acad. Sci. 762:222-237.

37. Stoyan, T., U. Michaelis, H. Schooltink, M. Van Dam, R. Rudolph, P.C. Heinrich, and S. Rose-John. 1993. Recombinant soluble human interleukin-6 receptor. Expression in Escherichia coli, renaturation and purification. Eur. J. Biochem. 216:239-245.

38. Walther, Z., L.T. May, and P. B. Sehgal. 1988. Transcriptional regulation of the interferon- $\beta_{2} / \mathrm{B}$ cell differentiation factor BSF-2/hepatocyte-stimulating factor gene in human fibroblasts by other cytokines. J. Immunol. 140: 974-977.

39. Sehgal, P.B. 1992. Regulation of IL6 gene expression. Res. Immunol. 143:724-734.

40. Akira, S., H. Isshiki, T. Nakajima, S. Kinoshita, Y. Nishio, S. Hashi- moto, S. Natsuka, and T. Kishimoto. 1992. A nuclear factor for the IL-6 gene (NF-IL6). Chem. Immunol. 51:299-322.

41. Akira, S., H. Isshiki, T. Sugita, O. Tanabe, S. Kinoshita, Y. Nishio, T. Nakajima, T. Hirano, and T. Kishimoto. 1990. A nuclear factor for IL-6 expression (NF-IL6) is a member of a C/EBP family. EMBO (Eur. Mol. Biol. Organ.) J. 9:1897-1906.

42. Matsusaka, T., K. Fujikawa, Y. Nishio, N. Mukaida, K. Matsushima, T. Kishimoto, and S. Akira. 1993. Transcription factors NF-IL6 and NF-кB synergistically activate transcription of the inflammatory cytokines, interleukin 6 and interleukin 8. Proc. Natl. Acad. Sci. USA. 90:10193-10197.

43. Dendorfer, U., P. Oettgen, and T.A. Libermann. 1994. Multiple regulatory elements in the interleukin- 6 gene mediate induction by prostaglandins, cyclic AMP, and lipopolysaccharide. Mol. Cell. Biol. 14:4443-4454. 